\title{
Study on the Impact of the Panama Canal Expansion on the Distribution of Container Liner Routes
}

\author{
Hanxun Fan*, Weihong Gu \\ College of Transport \& Communications, Shanghai Maritime University, Shanghai, China \\ Email: *apang@163.com
}

How to cite this paper: Fan, H.X. and Gu, W.H. (2019) Study on the Impact of the Panama Canal Expansion on the Distribution of Container Liner Routes. Journal of Transportation Technologies, 9, 204-214. https://doi.org/10.4236/jtts.2019.92013

Received: March 15, 2019

Accepted: April 9, 2019

Published: April 12, 2019

Copyright $\odot 2019$ by author(s) and Scientific Research Publishing Inc. This work is licensed under the Creative Commons Attribution International License (CC BY 4.0).

http://creativecommons.org/licenses/by/4.0/

\section{(c) () Open Access}

\begin{abstract}
The expansion of the Panama Canal will have a profound impact on the container shipping route network, port layout and ship structure, and promote the evolution of the global shipping pattern. However, most of the research on the expansion of the Panama Canal currently stays before its real expansion, and the quantitative analysis is less and the result is not accurate, because previous research used data that expanded before. Based on the actual data after the expansion of the Panama Canal, this paper uses the dual-target route distribution model to analyze the expansion of the Panama Canal. The changes in the liner shipping plan that have a greater impact on the shipping industry will provide the relevant theoretical basis for the relevant entities. The results show that after the expansion of the Panama Canal, the largest 15,000 TEU container ship is currently deployed on the route through the Panama Canal. 6500 TEU ship type is also deployed on the route through the Panama Canal. The 8500 TEU, 10,500 TEU, and 12,500 TEU ship types are mainly deployed through the Suez Canal. On the route, such a distribution plan can maximize the benefits for the shipping company.
\end{abstract}

\section{Keywords}

Panama Canal, Ocean Transport, Container Liner, Distributing Ships Model

\section{Introduction}

The Panama Canal is located in Panama, Central America, across the Isthmus of Panama, connecting the Pacific Ocean and the Atlantic Ocean. It is an important shipping route and is known as one of the Seven Wonders of the World and the

"World Bridge". It is one of the most important shipping waterways in the 
world, with about $6 \%$ of trade traffic passing through the canal every year. The Panama Canal is owned and managed by the Republic of Panama and belongs to the sluice canal. The coastline from one side to the other is about 65 kilometers long, and the deep water from the Caribbean Sea to the Pacific Ocean is about 82 kilometers deep, the wide area is 304 meters, and the narrowest place is 152 meters. Due to the increased demand for navigation and the burden of driving the national economy, this century-long waterway began to plan for the expansion in 2006 and completed the expansion plan in June 2016. After expansion, the canal can be loaded with a ship of 14,700 containers, which is three times of the front load. The expansion plan was originally scheduled to be completed during the 100th anniversary of the Canal in 2014, but due to the problems, the progress was slow and the completion time was extended to June 2016.

Currently, the five largest users of the Panama Canal are the United States, China, Mexico, Chile, and Japan. According to the information provided by the official website of the Panama Canal, $88 \%$ of the trade activities completed through the Panama Canal are trade goods between the United States and Asia, and $38 \%$ of the trade goods are related to China. The Panama Canal is China's main channel for import and export goods on the east coast of the United States. The widened Panama Canal will help the continued expansion of Sino-US trade activities. At the same time, economic and trade activities between China and Latin American countries are gradually increasing. Traveling through the Panama Canal is the most convenient route for Chinese vessels to travel to the Caribbean countries and the East Coast countries of South America. Although the tolls have increased after the expansion of the Panama Canal, the data obtained did not affect the throughput of the canal after the expansion. According to data from the Panama Canal official website, the total number of ships in the Panama Canal in 2016 was 13,114, and the number of ocean-going vessels was as high as 11,688. After the expansion, there were 13,584 ships and 12,000 ships in 2017, and 13,795 ships and 12,000 ships in 2018. According to the above analysis, the traffic volume of the Panama Canal is increasing year by year.

After the expansion of the Panama Canal, it can accommodate larger ships. The scale effect of the large-scale ship will have an impact on the distribution plan before the canal is widened. Based on the real data of the expansion of the Panama Canal, this paper re-integrates the liner resources on the two routes of the US East-Far East (through the Panama Canal) and the US East-Far East (through the Suez Canal) to achieve the most profitable purpose [1].

At present, experts have already done a lot of researches on the Panama Canal. FRANICISCO [2] [3] [4] [5] and other analysis of the laws and regulations and management status formed since the operation of the Panama Canal; BENFIELD [6] and GRA-HAM [7] explored the management capacity and operation of the canal from geographical features and temperature changes. Chinese scholars have analyzed the impact of the expansion of the Panama Canal on international trade, liner shipping and shipping from a qualitative perspective. 
For example: Jihong Chen [8] and others analyzed the impact of the expansion of the Panama Canal on the international container shipping pattern; Ruomei Wen [9] analyzed the impact of the expansion of the Panama Canal on world trade; Meijiang Cai [10] and Chengjun Liu [11] analyzed the impact of the expansion of the Panama Canal on shipping, and proposed China opportunities and corresponding development strategies. Yue Yin and Nanjun Jiang [12] proposed that the expansion of the Panama Canal brought great opportunities for the US East Port. At present, researches that studied the Panama Canal from a quantitative perspective are less. The current prosperity of international trade is closely related to the transportation of container containers the liner shipping of containers is the most able to reflect the impact of the Panama Canal on the expansion of Sino-US shipping. Therefore, this paper studies the distribution plan of the China-US East route that has a great impact on shipping after the expansion of the Panama Canal.

\section{Scenario Description and Model Building}

With the development of economic globalization, shipping has also made great progress as the most important way to communicate with the global economy. In the context of economic globalization, especially the trade between China and the United States has developed rapidly, which has led to trade development between Asia and the United States. As a necessary place to communicate the most economical routes between Asia and the United States, the Panama Canal has also been expanded to accommodate the trend of large-scale ships due to economic development. The widened Panama Canal has increased the competition for liner shipping companies operating in Asia and the United States. The lowest cost per container has become the goal of major shipping companies. Therefore, it is necessary to re-plan existing ship resources. This paper aims at the two that companies with the highest profit and the highest ship load rate.

According to the actual situation, add the following constraints to the model to ensure that the running results which have practical significance.

1) Ship resource restrictions, the number of ships on the route does not exceed the number of existing ships.

2) Frequency constraint, the sum of the number of flights operated by various ship types on a certain route during the planning period meets the number of annual flights at the determined ship-off frequency.

3) The voyage constraint, the sum of the annual operation time of a certain type of ship type on each route and the annual time less than or equal to the existing number of ships of the ship type during the planning period.

4) The demand for freight is constrained, and the capacity must meet the demand for the volume.

Based on the above constraints, the model with the largest profit and the highest load rate is assigned to calculate the income and cost, and the following model is obtained: 


$$
\left\{\begin{array}{l}
\max R=\sum_{z \in Z} M_{z o u t} q_{z o w n}+\sum f_{l} R_{l}-\sum_{z \in Z}\left(p_{1 z} R_{1}+2 p_{2 z} q_{z 2}\right) \\
\quad-\sum_{l \in L} \sum_{z \in Z}\left(M_{z o u t} Q_{\text {ozown }}+c_{z l} T_{z l}+M_{z i n} Q_{z i n}\right) \\
\frac{R_{l}}{\sum_{z \in Z} T_{z l} \times D_{z}} \geq \rho, \forall l \in L \\
\sum_{z \in Z} q_{z o w n} \leq Q_{\text {own }}, \quad \forall z \in Z \\
\sum_{z \in Z} q_{z i n} \leq Q_{i n}, \forall z \in Z \\
T_{z l} \geq M_{l}, \forall l \in L \\
T_{z l} \leq\left(Q_{o w n}+Q_{\text {in }}\right) \times\left[\left(365-\tau_{z}\right) / t_{z l}\right], \forall z \in Z, \forall l \in L
\end{array}\right.
$$

The model follows the total income minus the total cost to obtain the total profit. The total income includes the ship rental income $\left(\sum_{z \in Z} M_{z o u t} q_{z o w n}\right)+$ the freight income of the ship $\left(\sum f_{l} R_{l}\right)$, and the total cost includes the cost of the ship through the canal $\left(\sum_{z \in Z}\left(p_{1 z} R_{1}+2 p_{2 z} q_{z 2}\right)\right)+$ charter cost

$\left(\sum_{l \in L} \sum_{z \in Z} M_{z \text { zout }} Q_{\text {ozown }}\right)+$ voyage operating $\operatorname{cost}\left(\sum_{l \in L} \sum_{z \in Z} c_{z l} T_{z l}\right)+$ ship rental expenses $\left(\sum_{l \in L} \sum_{z \in Z} M_{z i n} Q_{z i n}\right)$. The following explains the parameters of the model and the variables.

$Q_{\text {own }}$ : the number of own $z$-type ships assigned to route 1 ;

$Q_{i n}$ : the number of rented $z$-type ships assigned to route $l$;

$T_{z i}$ the number of flights of the $z$-type ship on the $I$ route during the planning period;

$L=\{1,2\}$ is the liner route collection. $L=\{1\}$ is the route through the Panama Canal, that is, directly to the East Coast through the Panama Canal; $L=\{2\}$ is the route through the Suez Canal, that is, to cross the Atlantic Ocean through the Suez Canal to reach the East.

$Z=\{1,2,3,4,5\}$ is a collection of container types. $Z=\{1\}$ specifically refers to a container ship of $6500 \mathrm{TEU} ; z=\{2\}$ specifically refers to a container ship of 8500 TEU; $z=\{3\}$ specifically refers to a container ship of 10,500 TEU; $z=\{4\}$ specifically refers to a container of 12,500 TEU Ship; $z=\{5\}$ specifically refers to a 15,000 TEU container ship.

$M_{z i n}$ : rented rent for $z$-type container ships;

$M_{\text {zoui }}$ rental and rental of $z$-type container ships;

$Q_{\text {zown }}$ the number of own $z$-type container ships;

$Q_{z i n}$ : the number of ships that can be rented into $z$-type containers;

$f_{i}$ the average freight rate of containers on the Panama Canal route (unit: USD/TEU);

$R_{i}$ The total annual transportation demand of 1 route (unit: TEU);

$P_{1 z}$ Panama Canal toll for $z$-type container ships on the eastbound route (unit: $\mathrm{USD} / \mathrm{TEU})$;

$P_{2 z}:$ Suez Canal navigation fee for $z$-type container ships on the westbound route (in US dollars);

$C_{z l}$ the operating cost of a single round-trip voyage on the $Z$-type container ship on the I route;

$T_{z i}$ the sailing time of a single round-trip voyage of a $Z$-type container ship on 
the I route;

$\tau_{z}$ the number of idle days of $Z$-type container ships;

$M_{\dot{r}}$ the minimum number of flights required to meet the weekly service and route;

$D_{Z}$ : single ship capacity of $Z$-type container ships;

$V_{Z}$ : economical speed of $Z$-type container ships (Note: 1 knot $=1$ nautical mile $/$ hour $=1.852 \mathrm{~km} / \mathrm{h}$ ).

\section{Empirical Analysis}

The widening of the Panama Canal has an impact on container liner shipping in the American East-Far East. The largest container ship that can be passed before the Panama Canal was widened was 4500 TEU. The smallest ship type applied after widening has reached $6500 \mathrm{TEU}$, The largest ship type that can be passed is 15,000 TEU. Data collection based on the parameters mentioned in the model established in the previous section.

\subsection{Various Types of Ship Parameters}

From Table 1, the economies of scale brought about by the large-scale ship can be intuitively obtained, Although container ships with larger payloads are slower in service speed than container ships with smaller payloads, there is an absolute advantage in container ships with a larger average daily fuel consumption. This advantage is not only reflected in the economy, but also in the environmental protection. Large ships can guarantee energy consumption based on reduced energy consumption.

\subsection{Various Types of Ship Operating Hours}

Table 2 and Table 3 show the timing of the two types of routes through the Panama Canal and the Suez Canal, which are needed in the final distribution model.

\subsection{Route Cost of Various Ship Types}

Based on the actual situation, the following assumptions are made.

1) The liner shipping company does not change the original port of call. The reduced capacity is only used for renting. The increased capacity is only from renting.

2) Do not consider other types of costs mentioned in the text.

3) The costs and profits in the route are all divided according to the two routes given in the article.

4) All types of ships are economical service speeds when serving on the route, regardless of the difference between ballast and heavy load.

Table 4 presents the various cost calculation rules, including fixed costs and variable costs through the Panama Canal and the Suez Canal.

Table 5 shows the specific values of fixed costs, which are needed in the dis- 
tribution model.

Table 6 shows the variable cost of the route through the Panama Canal, which is part of the final total cost and is needed in the distribution model. Specifically, it can be searched from the parameters in the ship model, and the data in the table is used for calculation.

Table 7 shows the variable cost of the route through the Suez Canal, which is part of the final total cost and is needed in the distribution model. Specifically, it can be searched from the parameters in the ship model, and the data in the table is used for calculation.

In order to meet the calculation requirements of the distribution ship, the average freight rates of the two routes of the Panama Canal and the Suez Canal were calculated, the average freight rate of the Panama Canal is p1: 3087.5 US dollars/TEU; the average freight rate over the Suez Canal is p2: 1647 US dollars/TEU.

Source:

http://www.sofreight.com/freight_from_to__10d0s0t0w0p1_by_0_carrier_c0.h tml.

Ships also need to pay the corresponding river crossing fees through the canal. The cost of passing the Panama Canal is shown in Table 8, and the cost of passing the Suez Canal is shown in Table 9.

Table 1. Ship parameters of various types.

\begin{tabular}{cccccc}
\hline & Ship type 1 & Ship type 2 & Ship type 3 & Ship type 4 & Ship type 5 \\
\hline Ship specification (TEU) & 6500 & 8500 & 10,500 & 12,500 & 15,000 \\
dwt & 67,500 & 95,000 & 121,824 & 125,000 & 165,000 \\
Average daily fuel & 228 & 248 & 173.2 & 155 & 137.1 \\
consumption (t/d) & & & & 23 & 22.5 \\
Service speed (knot) & 25.4 & 26 & 22.8 & 40 & 50 \\
$\begin{array}{c}\text { Annual repair days (d) } \\
\text { Number of own s-ships }\end{array}$ & 60 & 30 & 20 & 3 & 3 \\
$\begin{array}{c}\text { Number of s-ships } \\
\text { available for rent }\end{array}$ & 3 & 2 & 6 & 4 & 3 \\
\hline
\end{tabular}

Source: Clarkson research

Table 2. Operation time of the route through the Panama Canal.

\begin{tabular}{cccccc}
\hline & Ship type 1 & Ship type 2 & Ship type 3 & Ship type 4 & Ship type 5 \\
\hline $\begin{array}{c}\text { Voyage sailing } \\
\text { time (days) }\end{array}$ & 40 & 39 & 38 & 37 & 36 \\
$\begin{array}{c}\text { Voyage time in } \\
\text { port (days) }\end{array}$ & 27 & 27 & 27 & 27 & 27 \\
$\begin{array}{c}\text { Voyage time } \\
\text { (days) }\end{array}$ & 67 & 66 & 65 & 64 & 63 \\
$\begin{array}{c}\text { Annual number } \\
\text { of flights (times) }\end{array}$ & 4 & 5 & 5 & 5 & 4 \\
\hline
\end{tabular}


Table 3. Operating time of the route through the Suez Canal.

\begin{tabular}{cccccc}
\hline & Ship type 1 & Ship type 2 & Ship type 3 & Ship type 4 & Ship type 5 \\
\hline $\begin{array}{c}\text { Voyage sailing } \\
\text { time (days) }\end{array}$ & 54 & 52 & 51 & 50 & 49 \\
$\begin{array}{c}\text { Voyage time in } \\
\text { port (days) }\end{array}$ & 24 & 24 & 24 & 24 & 24 \\
$\begin{array}{c}\text { Voyage time } \\
\text { (days) }\end{array}$ & 78 & 76 & 75 & 74 & 73 \\
$\begin{array}{c}\text { Annual number } \\
\text { of flights (times) }\end{array}$ & 3 & 4 & 4 & 4 & 4 \\
\hline
\end{tabular}

Table 4. The source of the route cost of each type of ship is summarized as follow [13].

\begin{tabular}{|c|c|}
\hline Type of fee & Value basis \\
\hline Ship cost & $\begin{array}{c}\text { The average cost of Clarkson's similar } \\
\text { ship type in the past three years. }\end{array}$ \\
\hline staff salary & $\begin{array}{l}\text { The number of crew members of ocean-going } \\
\text { container ships and the number of crews } \\
\text { equipped with various types of ships, the number } \\
\text { of crew members of ocean-going container ships } \\
\text { and the number of crew members of various } \\
\text { types of ships. }\end{array}$ \\
\hline Ship depreciation & $\begin{array}{l}\text { Depreciation period positioning for } 15 \text { years, } \\
\text { depreciation by straight-line depreciation } \\
\text { method, the original value is } 10 \% .\end{array}$ \\
\hline Annual repair fee & $3 \%$ of Ship price. \\
\hline Annual insurance premium & $\begin{array}{l}\text { In this case, the new ship with a ship age of } 1-3 \\
\text { years, the insurance rate is } 0.2 \% \text { of the ship price. }\end{array}$ \\
\hline Annual fuel cost & $\begin{array}{l}\text { Host power }{ }^{*} \text { fuel consumption rate }{ }^{*} \text { voyage } \\
\text { time }{ }^{\star} \text { fuel price }{ }^{\star} \text { annual number of flights. }\end{array}$ \\
\hline Annual lubricant fee & $8 \%$ of annual fuel costs. \\
\hline Annual material fee & $10 \%$ of the annual fuel and lubricant costs. \\
\hline Annual port fee & $\begin{array}{c}\text { Cost per dwt per voyage }(\$ 3.6 / \text { ton }) * \text { Deadweight } \\
\text { tons }{ }^{*} \text { annual flight times. }\end{array}$ \\
\hline Management fees and other district fees & $15 \%$ of total operating expenses. \\
\hline
\end{tabular}

Table 5. Annual fixed costs for various ship types (\$).

\begin{tabular}{|c|c|c|c|c|c|}
\hline & Ship type 1 & Ship type 2 & Ship type 3 & Ship type 4 & Ship type 5 \\
\hline Ship cost & $60,000,000$ & $83,000,000$ & $93,000,000$ & $108,000,000$ & $147,000,000$ \\
\hline Staff salary & 839,964 & 839,964 & 942,684 & 942,684 & $1,045,404$ \\
\hline $\begin{array}{l}\text { Annual ship } \\
\text { depreciation }\end{array}$ & $3,600,000$ & $49,800,000$ & $55,800,000$ & $64,800,000$ & $88,200,000$ \\
\hline Annual repair fee & $1,800,000$ & $2,490,000$ & $2,790,000$ & $3,240,000$ & $4,410,000$ \\
\hline $\begin{array}{c}\text { Annual insurance } \\
\text { premium }\end{array}$ & 120,000 & 166,000 & 186,000 & 216,000 & $2,940,000$ \\
\hline
\end{tabular}

Source: Clarkson research. 
Table 6. Variable costs of various types of ships on the Panama Canal route (\$).

\begin{tabular}{cccccc}
\hline & $\begin{array}{c}\text { Ship } \\
\text { type } 1\end{array}$ & $\begin{array}{c}\text { Ship } \\
\text { Type } 2\end{array}$ & $\begin{array}{c}\text { Ship } \\
\text { Type } 3\end{array}$ & $\begin{array}{c}\text { Ship } \\
\text { Type } 4\end{array}$ & $\begin{array}{c}\text { Ship } \\
\text { type 5 }\end{array}$ \\
\hline $\begin{array}{c}\text { Annual } \\
\text { fuel cost }\end{array}$ & $9,312,000$ & $13,800,384$ & $14,314,581$ & $14,024,018$ & $10,983,038$ \\
$\begin{array}{c}\text { Annual } \\
\text { lubricant fee }\end{array}$ & 744,960 & $1,104,031$ & $1,145,166$ & $1,121,921$ & 878,643 \\
$\begin{array}{c}\text { Annual } \\
\text { material fee }\end{array}$ & $1,005,696$ & $1,490,441$ & $1,545,974$ & $1,514,594$ & $1,186,168$ \\
Annual \\
port fee
\end{tabular}

Source: Clarkson research.

Table 7. Variable costs of various ship types on the Suez Canal route (\$).

\begin{tabular}{|c|c|c|c|c|c|}
\hline & $\begin{array}{l}\text { Ship } \\
\text { type } 1\end{array}$ & $\begin{array}{c}\text { Ship } \\
\text { Type } 2\end{array}$ & $\begin{array}{c}\text { Ship } \\
\text { Type } 3\end{array}$ & $\begin{array}{l}\text { Ship } \\
\text { Type } 4\end{array}$ & $\begin{array}{l}\text { Ship } \\
\text { Type } 5\end{array}$ \\
\hline $\begin{array}{l}\text { Annual } \\
\text { fuel cost }\end{array}$ & $10,578,664$ & $14,720,410$ & $15,369,340$ & $15,161,100$ & $14,949,136$ \\
\hline $\begin{array}{c}\text { Annual } \\
\text { lubricant fee }\end{array}$ & 846,293 & $1,177,633$ & $1,229,547$ & $1,212,888$ & $1,195,931$ \\
\hline $\begin{array}{c}\text { Annual } \\
\text { material fee }\end{array}$ & $1,142,496$ & $1,589,804$ & $1,659,889$ & $1,637,390$ & $1,614,507$ \\
\hline Annual port fee & 729,000 & $1,368,000$ & $1,754,266$ & $1,800,000$ & $2,376,000$ \\
\hline $\begin{array}{c}\text { Annual management } \\
\text { fee and other }\end{array}$ & $14,019,529$ & $27,306,719$ & $30,400,784$ & $34,414,408$ & $45,950,956$ \\
\hline $\begin{array}{c}\text { Annual } \\
\text { operating cost }\end{array}$ & $27,315,982$ & $46,162,566$ & $50,413,826$ & $52,752,135$ & $66,086,530$ \\
\hline $\begin{array}{c}\text { Voyage } \\
\text { operating cost }\end{array}$ & $9,105,327$ & $11,540,641$ & $12,603,456$ & $13,188,033$ & $16,521,632$ \\
\hline
\end{tabular}

Table 8. Panama Canal navigation fee (\$/TEU).

\begin{tabular}{|c|c|c|c|c|c|}
\hline $\begin{array}{c}\text { Annual container } \\
\text { volume (TEU) \ship type }\end{array}$ & $\begin{array}{l}\text { Ship } \\
\text { type } 1\end{array}$ & $\begin{array}{l}\text { Ship } \\
\text { type } 2\end{array}$ & $\begin{array}{l}\text { Ship } \\
\text { type } 3\end{array}$ & $\begin{array}{l}\text { Ship } \\
\text { type } 4\end{array}$ & $\begin{array}{l}\text { Ship } \\
\text { type } 5\end{array}$ \\
\hline $1,500,000 \mathrm{TEU} \leq \mathrm{T} 1$ & 47 & 47 & 47 & 47 & 47 \\
\hline $1,000,000 \mathrm{TEU} \leq \mathrm{T} 1 \leq 1,500,000 \mathrm{TEU}$ & 48 & 48 & 48 & 48 & 48 \\
\hline $450,000 \mathrm{TEU} \leq \mathrm{T} 1 \leq 1,000,000 \mathrm{TEU}$ & 49 & 49 & 49 & 49 & 49 \\
\hline \multicolumn{6}{|l|}{ Source: https://www.pancanal.com } \\
\hline
\end{tabular}


Table 9. Suez Canal container ship navigation fee (\$).

\begin{tabular}{cccccc}
\hline & $\begin{array}{c}\text { Ship } \\
\text { type 1 }\end{array}$ & $\begin{array}{c}\text { Ship } \\
\text { type 1 }\end{array}$ & $\begin{array}{c}\text { Ship } \\
\text { type 1 }\end{array}$ & $\begin{array}{c}\text { Ship } \\
\text { type 1 }\end{array}$ & $\begin{array}{c}\text { Ship } \\
\text { type 1 }\end{array}$ \\
\hline $\begin{array}{c}\text { Suez Canal net } \\
\text { registration tonnage }\end{array}$ & 61,353 & 81,804 & 102,255 & 122,706 & 153,383 \\
$\begin{array}{c}\text { Navigation fee (Special } \\
\text { Drawing Rights, SDR) }\end{array}$ & 225,544 & 274,529 & 318,498 & 362,197 & 425,084 \\
$\begin{array}{c}\text { Navigation } \\
\text { fee (\$) }\end{array}$ & 317,114 & 385,987 & 447,809 & 509,249 & 597,668 \\
\hline
\end{tabular}

Explain: 1 SDR = 1.406 USD, Source: Suez Canal official website.

Table 10. The result of matching ships.

\begin{tabular}{|c|c|c|c|c|c|c|}
\hline & \multicolumn{3}{|c|}{ Through the Panama Canal } & \multicolumn{3}{|c|}{ Through the Suez Canal } \\
\hline & $\begin{array}{l}\text { Own } \\
\text { ships }\end{array}$ & $\begin{array}{c}\text { Chartered } \\
\text { ships }\end{array}$ & $\begin{array}{c}\text { Number of } \\
\text { flights }\end{array}$ & $\begin{array}{l}\text { Own } \\
\text { ships }\end{array}$ & $\begin{array}{c}\text { Chartered } \\
\text { ships }\end{array}$ & $\begin{array}{c}\text { Number of } \\
\text { flights }\end{array}$ \\
\hline $\begin{array}{l}\text { Ship } \\
\text { type1 }\end{array}$ & 2 & 3 & 22 & & & \\
\hline $\begin{array}{l}\text { Ship } \\
\text { Type2 }\end{array}$ & & 1 & 5 & 2 & 4 & 26 \\
\hline $\begin{array}{l}\text { Ship } \\
\text { Type3 }\end{array}$ & 1 & 5 & 31 & 3 & 1 & 18 \\
\hline $\begin{array}{l}\text { Ship } \\
\text { Type4 }\end{array}$ & & 1 & 5 & 3 & 3 & 26 \\
\hline $\begin{array}{c}\text { Ship } \\
\text { Type5 }\end{array}$ & 2 & 3 & 24 & & & \\
\hline
\end{tabular}

Since the east-west loading rate is different, it is assumed that the average cargo loading rate is $70 \%$, that is, $\rho=70 \%$ in the model, which simplifies the calculation and transforms a double-objective problem into a single-objective integer programming problem. It can be solved with the optimization software lingo [14] [15].

Table 10 shows the distribution of the Panama Canal and the Suez Canal. This type of distribution plan can maximize economic benefits.

\section{Conclusions}

It can be seen from the results of the ship distribution that after the expansion of the Panama Canal, the large container ships will be deployed on the routes through the Panama Canal to obtain greater economic benefits [16] [17] [18]. However, due to the resource constraints of large ships, the 15,000 TEU container ships were not deployed on routes passing the Suez Canal with a longer distance. The reason for this result is that: first, the effect of large-scale ships after the expansion of the Panama Canal is obvious. And the impact on the Suez Canal after the expansion of the Panama Canal, the Suez Canal's ability to collect goods is insufficient, so this has happened. Secondly, as the Panama Canal ex- 
pands the development of ports along Central America and the Caribbean, many liners need to be transited in ports in Central America and the Caribbean. This is the reason why the smaller ship type is configured in the Panama Canal. Subject to the limitations of ship-type resources, the liner transfer business through the Suez Canal can only be completed by the ship type 2 ( 8500 TEU), which is the maximum benefit allocation.

After the expansion of the Panama Canal, the most direct impact is that it can pass the larger ship type, and the 15,000 TEU option can be added to the ship plan. At the same time, the mileage of the large ship is reduced, thereby reducing the time of the round trip and finally reducing the single box cost. For the shipping company, it is necessary to make corresponding adjustments according to the distribution plan, such as adjusting the chartering plan, renting a 15,000 TEU ship type on the route through the Panama Canal to obtain greater economic benefits, while strengthening the route through the Panama Canal. At the same time, we will strengthen our ability to collect cargo on the Panama Canal route and maximize the benefits of large-scale ships.

In addition, in order to adapt to the current trend of large-scale ships, the infrastructure of the East Coast Port Group should also follow the development trend. At present, the US East Port can only provide services for traditional Panamax vessels. The capacity of the US East Port Group cannot support the docking of 15,000 TEU container ships. As the volume of cargo increases, the collection and distribution system of the US East Port Group also needs to be upgraded to match the increase in the volume of goods. The follow-up can further study the collection and distribution system of the US East Port and to be perfect the impact of the Panama Canal widening on shipping.

\section{Conflicts of Interest}

The authors declare no conflicts of interest regarding the publication of this paper.

\section{References}

[1] Zeng, Q.C., Wu, K. and Sun, X.J. (2016) The Impact of Panama Canal Expansion on the Choice of Container Transportation Paths between China and the United States. China Navigation, 39, 109-113.

[2] Montero Llacer, F.J. (2004) Panamanian Maritime Sector Management. Marine Policy, 28, 283-295. https://doi.org/10.1016/j.marpol.2003.09.007

[3] Montero Llacer, F.J. (2005) Panama Canal Mangement. Marine Policy, 29, 25-37. https://doi.org/10.1016/j.marpol.2004.02.001

[4] Montero Llacer, F.J. (2005) Panama Canal: Operations and Traffic. Marine Policy, 29, 223-234.

[5] Montero Llacer, F.J. (2006) Port Privatization in Panama. Marine Policy, 30, 483-495. https://doi.org/10.1016/j.marpol.2005.06.017

[6] Benfield, S.L., Guzman, H.M. and Mair, J.M. (2005) Temporal Mangrove dynamics in Relation to Coastal Development in Pacific Panama. Journal of Environmental 
Management, 76, 263-276. https://doi.org/10.1016/j.jenvman.2005.02.004

[7] Graham, N.E., Georgakakos, K.P., Vargas, C. and Echevers, M. (2006) Simulating the Value of E1 Nino Forecasts for the Panama Canal Advances in Water Resources, 19, 1665-1677.

[8] Chen, J.H., Cao, Y., Liang, X.F., et al. (2013) The Impact of the Expansion of the Panama Canal on the International Container Shipping Pattern. China Navigation, 1, 73-76.

[9] Wen, R.M. (2007) The Expansion of the Panama Canal Has a Profound Impact on Global Trade. World News.

[10] Cai, M.J. (2008) Expansion of the Panama Canal and Its Impact on World Shipping. China Ocean Shipping, 2, 69-71.

[11] Liu, C.J. and Jin, X.F. (2009) Expansion of the Panama Canal and the Prospect of Transportation. Tianjin Navigation, 2, 49-51.

[12] Yin, Y. and Jiang, N.X. (2007) The Expansion of the Panama Canal Is in the East Port of Hong Kong. The port Economy, 5, 54-55.

[13] Xie, X.L. (2009) Ship Transportation Management and Management. Dalian Maritime University Press, Dalian.

[14] Yang, H.L. and Zhong, M. (1996) Research on Optimization Decision-Making of Container Liner Shipping. Journal of Dalian Maritime University, 22, 51-54.

[15] Yu, S.M. (1997) Mathematical Optimization Method for Ships on Liner Routes. Traffic and Computer, 15, 44-45.

[16] Jiang, J.W. (2009) The Impact of the Financial Crisis on the Expansion of the Panama Canal. Water Transport Management, 6, 38-39.

[17] Li, Y. (2012) New Panamax Container Ship Design Defect. China Ship Inspection, 5, 69-69.

[18] Chen, S.L. (2011) The Scale Line of Sight and Layout Requirements of the Panama Canal to Navigation Vessels. Ship, 12, 1-5. 